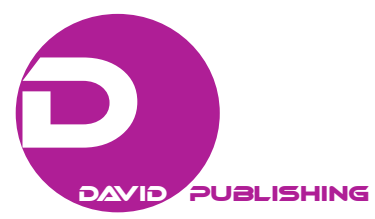

\title{
The Politics of War Apology: From Murayama to Abe
}

\author{
Arthur Stockwin \\ University of Oxford, Oxford, UK
}

\begin{abstract}
The issue of war apology remains important and controversial within Japan today, and between Japan and her neighbors. Since the 50th anniversary of the Japanese defeat on 15th August 1945, it has become customary for the Prime Minister to make a considered statement, normally including an apology for Japanese wartime atrocities and related issues. On 15th August 1995 the Socialist Prime Minister Murayama made a fulsome and unambiguous apology, which has been seen as the "gold standard" by countries at which it was directed, notably China and South Korea. The conservative Koizumi made a similar apology 10 years later. On 15th August 2015 the radical right wing Prime Minister Abe made a lengthy statement, interleaving apologies with explanations and justifications of Japan's past actions. This article analyses the texts of these and other relevant statements, and concludes that current war apology exercises are seriously undermined by the radical statements and policies of the Abe Government.
\end{abstract}

Keywords: Japanese politics, war apology, Abe Shiro, Murayama Tomiichi, Koizumi Junichiro

\section{Introduction}

The election of the Abe Government in December 2012 launched a period of nationalistic revisionism in Japanese politics. This was not unprecedented, in the sense that several previous prime ministers (in the recent past most obviously Koizumi Junichirō) had used nationalistic themes in some of their rhetoric - and in Koizumi's case conspicuously in his several visits to the Yasukuni Shrine during the five and half years (2001 to 2006) during which he was prime minister.

The emergence of Abe, however, represents a major shift towards an energetic nationalism, with constitutional revision, enhancement of the role of the Self Defence Forces, a desire to confront Chinese expansionism in East Asia, greater control over information and the mass media, restrictions on human rights and radical reassessment of both the Asia-Pacific War and the Allied Occupation, in the new government's sights. This was in fact the second period in office as prime minister for Abe, since he had succeeded Koizumi in 2006, though he lasted only a year. The end of 2012 saw the collapse of a failed three-year experiment in replacement of the long term "party in power" (LDP) by the main opposition Democratic Party of Japan (DPJ). The DPJ Government failed because of inexperience, internal dissent, poor leadership and the triple disasters of force nine earthquake, devastating tsunami and meltdown at the reactors of the Fukushima No. 1 nuclear power station on 11th March 2011 (now known as 3/11), so that once the LDP was back in power, it faced a weak and debilitated opposition. Moreover, the LDP itself, which used to be a kind of coalition between different ideological strands led by strong leaders balancing each other's power, had become less factionalized, and more united around a single ideological approach, combining a strategy for economic revival with the aim of diluting post-war democratic and pacifist reforms with a nationalistic and revisionist agenda.

Arthur Stockwin, Emeritus Fellow, St Antony's College, University of Oxford. 
A further factor that goes some way to explain the trend towards more nationalistic attitudes in Japan (and may have contributed to Abe's victory in the 2012 general elections) is the rise of China. Japan has been overtaken by China as the second largest economy in the world, and the dispute over the uninhabited Senkaku (Diaoyu) islands in the East China Sea has deepened the unpopularity of the Chinese regime within Japanese public opinion. It is beyond the scope of this article to discuss Japanese relations with South and South-East Asia, as well as Australasia, but generally speaking relations are less fraught with controversy than between Japan and its more northerly neighbors. Both Australia and India, for instance, now have defence agreements with Japan.

Relationship with neighbors does not, however, appear to be the most important motivation for the Abe Government's attempts to rehabilitate the reputation of what Japan was trying to achieve in the Asia-Pacific War. The influence of his grandfather, the former prime minister Kishi Nobusuke, who was part of the wartime regime (and earlier, a powerful minister in the Japanese puppet State of Manchukuo), runs deep in Abe's thinking about history (Abe, 2006).

In this paper the author wishes to examine one aspect of the Abe Government agenda, that of revisiting the issue of war apology. This is an issue that may well arise after any serious war, but in the case of Japan and its immediate neighbors it has developed with unusual intensity and persistence, particularly in recent decades. Even though countries neighboring Japan regularly complained about a Japanese lack of contrition for atrocities committed - especially in China - during the war, in fact there had been a number of apologies by Japanese leaders that contained real substance. In assessing war apologies made during the period of the Abe Government, it may seem natural to take what is said or written at face value, and evaluate it as such. The key argument of this paper, however, is that the official apologies should be seen inseparably from a deliberately stage managed contrary discourse, whereby the "apology industry" has been repeatedly denigrated by Prime Minister Abe and those close to him, or of similar opinions. The result of this has been that apologies have been issued to satisfy international opinion, but they are hollowed out, or robbed of meaning, by the contrary discourse that has been developed in parallel.

The most important and most reflective previous war apology, to which we shall devote the first section of this paper, was the Murayama statement delivered on the 50th anniversary of the defeat, on 15th August 1995.

We shall also discuss later apologies, as well as the Kōno statement of August 1993, concerning the issue of the euphemistically described "comfort women", which raised the contentious issue of how far the women concerned (the bulk of them from Korea) had been coerced into prostitution and badly treated while providing sexual services to soldiers in army "comfort stations" (meaning brothels).

The concluding section of the paper will discuss the ways in which the second Abe administration has treated earlier war apologies, and will address the apparent contradiction between its frequent criticisms of these previous war apologies and the Prime Minister's statements that the Government "continues to observe them" (keishō suru, tōshī suru, or uketsugu). The author will argue that the Abe Government has developed a sophisticated and calculated approach to this issue. Prime Minister Abe made a statement to mark the 70th anniversary of the war in the Asia-Pacific on 15th August 2015, which may be regarded as the considered summation of his approach towards war apology. It was longer than expected, and also made extensive concessions to international demands for apology, but the qualifications made were subtle and important, so that the real significance of what he actually said on 15th August needs the most careful scrutiny. 


\section{The 1995 Murayama Statement}

On the 50th anniversary of the ending of the Asia-Pacific War, 15th August 1995, the Japanese Prime Minister, Murayama Tomiichi, made what must be seen as the most complete apology by a top Japanese leader since the end of the war. In the years since it was issued by Japan's only Socialist prime minister since 1948, it has functioned as a kind of "gold standard" by which later apologies are judged by countries neighboring Japan. By contrast, the nationalistic hard right ${ }^{1}$ in Japan regards it with suspicion and hostility.

It is the fifth paragraph of the Murayama apology that is most frequently quoted, and whose language has become the most controversial. Let me quote the paragraph in full:

Our country, at a time in the not distant past, was mistaken in its national policy, treading a path to war, fell into a life and death crisis for the people, and through colonial domination and aggression, inflicted enormous damage and suffering to the peoples of many countries, including especially those of Asia. Because I do not wish that we should repeat these mistakes in the future, I humbly accept this undeniable historical truth, and here once again expressing my acute reflection I express my sentiment of heartfelt apology. And I offer my profound condolences to the domestic and foreign victims that this war created. (para. 5)

The paragraph contains a number of words that have become the subject of dispute, including "mistaken, mistakes" (ayamari), "colonial domination and aggression" (shokuminchi shihai to shinryaku), "remorse" (hansei) and most significantly of all "apology" (o-wabi). It is these last two words that have caused the greatest difficulties between Japan and her neighbours. Hansei, on the one hand, though most commonly translated as "remorse", might also be seen as meaning "reflection", "searching one's conscience", "self-examination", "regret", or "being sorry for". $O$-wabi, on the other hand, means "apology" (though it can also carry the meaning of "excuse"), and thus is less nuanced and clearly stronger. At any rate, representatives of the countries neighboring Japan have come to interpret any wording that falls short of $o$-wabi (including hansei) as implying that they have been short-changed. There is a further word—shazai-which is stronger than $o$-wabi, but it is rarely used in speech.

All these indicate that the politics of Japanese war apology has become something of an exercise in linguistic interpretation, or (to put it more harshly) of legalistic pedantry. This is, however, what the media tend to concentrate on.

It seems a good idea to go beyond such matters, and examine the broader context in which they were placed in the Murayama statement of 1995.

The first paragraph of the statement reads as follows:

Fifty years have elapsed since the Second World War came to an end. Now that so many people at home and abroad who were sacrificed in that war are once again in people's thoughts, a mixture of emotions troubles our hearts.

\footnotetext{
${ }^{1}$ By "nationalistic hard right", and similar expressions later in this article is meant those in or sympathetic to the Abe Government who are ideologically out of sympathy with the ideals of the post-war settlement embodied in the 1947 Constitution, sceptical about democracy as a governing principle of politics, resistant to the principle of freedom of information, determined to inculcate "patriotism" as a ruling principle of education and to maintain strict control over school textbooks, especially those relating to national history, desiring to reduce the scope of human rights in favor of duties to the State, favorable to forward defence policies, especially in relation to China, and nostalgic about aspects of the pre-war system of governance under the Meiji Constitution of 1889. It is worth noting that nearly all ministers in the Abe Cabinet late in 2015 were members of the Nippon Kaigi (Japan Association), an organization with close links to far right wing groups, with many ministers also being members of the Shintō Seiji Renmei (Shinto Political League), which demands a privileged position for the Shinto religion, which up to 1945 was one of the instruments of State policy.
} 
Murayama's second paragraph praises Japan's recovery after the war, and gives thanks for international help, especially from the US, but also from Asian neighbors and the countries of Europe.

The third paragraph, longer than the others, speaks of the need to avoid past mistakes, to "transmit to younger generations knowledge about the misery of war", and foster relations of understanding and trust with neighboring countries. It also refers to the conduct of historical research and "management" of post-war issues, to promote good relations.

Paragraph four, brief, emphasizes the need to learn lessons from history.

The crucial fifth paragraph we have discussed earlier, and the sixth and final paragraph reads as follows:

Today, when we have reached the 50th anniversary of the ending of the war, we must engage in profound reflection, reject dictatorial nationalism, promote international solidarity as a member of a responsible international society, and through this work to expand the principle of peace, as well as democracy. At the same time it is crucial for Japan, as the only country to have undergone the experience of nuclear bombing, to aim for the final abolition of nuclear weapons, as well as the strengthening of the nuclear non-proliferation regime, and promote international disarmament in a positive fashion. I believe that it is this that is true atonement for the past, and may console the spirits of those who were the victims. $^{2}$

It is important to understand the political situation in which the Murayama statement was devised and uttered. This was a period in which the government was a coalition among the LDP, the Japan Socialist Party (JSP) and the small Sakigake party, with the Socialist Murayama as Prime Minister, following the collapse of the multi-party coalition excluding the LDP a year earlier, in June 1994. The main opposition party was now the Shinshintō (New Frontier Party), consisting of the main elements from the earlier coalition, exclusive of the Socialists and Sakigake. On 9th June 1995, the House of Representatives passed a resolution entitled "Resolution to renew our will for peace through the lessons of history". It was, however, only the three government parties that voted in favor of the resolution, since the Shinshintō members (as well as some from the LDP and JSP) absented themselves from the vote. The resolution was very short, and much criticized for its inadequacy. Moreover, though the resolution was carried by a majority of those present, voting took place with many members absent, so that those in favor were a minority of the House taken as a whole. The resolution read as follows:

This House, now that 50 years have elapsed since the end of the war, presents our sincere tribute to those throughout the world who died in war, and those who were victims of war.

We also think of many instances of colonial domination and aggressive types of behavior (shinryakuteki kōi) in modern world history, we recognize behavior of this kind on the part of our country in the past, and the damage that we inflicted on the people of other countries, especially those of Asia, and we express out deep sense of remorse (hansei).

We must overcome differences of historical perspective concerning past wars, humbly learn lessons from history, and build a peaceful international society.

This House, based on the principle of eternal peace embodied in the Japanese Constitution, holds out our hands to the countries of the world, and here expresses our resolution to create a future of harmony for mankind.

We so resolve. ${ }^{3}$

Prime Minister Murayama expressed the view that he regarded what had happened as regrettable, having

\footnotetext{
${ }^{2}$ Full text of the Murayama statement given in Asahi Shinbun, 4th March 2015.

${ }^{3}$ Asahi Shinbun, 10th June 1995.
} 
tried up to the last minute to persuade the Shinshinto to participate in the vote. ${ }^{4}$ What was to become the key vocabulary of $o$-wabi and ayamari were conspicuous by their absence.

Between June and August the Prime Minister prepared a far stronger statement, reflecting his own peace-centered philosophy, and expressing an apology in unambiguous terms, as we have seen. It is reported that a draft of the statement was made early in July by his adviser, Yano Sakutarō, who came from the Ministry of Foreign Affairs. In this draft, Yano replaced the half-way-house term "aggressive types of behavior", by the unambiguous "aggression". He, however, hesitated to use the o-wabi (the apology "gold standard"), feeling that at that stage the issue of apology was not central in Japan-China and Japan-South Korea discussions. Other advisers, however, and also Murayama's Chief Cabinet Secretary, Sonoda Hiroyuki, thought that since the world was watching, o-wabi should be incorporated in the statement. By 7th August, the statement was ready in its final form. It was also approved by Kōno Yōhei, the LDP President, who was apparently relieved to have a statement incorporating an unequivocal apology, in face of the widespread criticism to which the half-hearted parliamentary statement had attracted. ${ }^{5}$

One potential obstacle was the formidable International Trade and Industry Minister, Hashimoto Ryūtarō (who was to succeed Murayama as Prime Minister in January 1996), and was Chairman of the Japanese Association of Bereaved Families (Nihon Izokukai). According to Murayama's memoirs, this apparently hawkish politician suggested just one amendment, namely that "end of the war" (shüsen) should be changed to "defeat" (haisen) (Yakushiji, 2012, p. 218; ). ${ }^{6}$ Since "defeat" was widely regarded in conservative circles as a taboo term, this was a remarkable reaction from a politician close to ex-service groups. It may well reflect the great difference in political atmosphere between 1995 and 2015, between which dates the political spectrum has moved dramatically to the nationalistic right.

\section{The 2005 Koizumi Statement}

Much less well known than the Murayama statement is the Koizumi statement made on the 60th anniversary of the end of the war, on 15th August 2005. Given the great differences of political outlook between the two men, it is perhaps surprising that Koizumi should have followed so closely the wording of the Murayama statement. It should be remembered that Koizumi at the time was in the middle of the great crisis over the rejection in the House of Councillors of his postal services privatization bill, so that he may have paid less attention to the wording of the statement than he might otherwise have done. The language is more concise, but the sentiments not so different.

Let us cite the statement's key paragraph, which we may compare with the equivalent paragraph in Murayama's statement 10 years earlier:

Also, our country formerly, through colonial domination and aggression, inflicted enormous damage and suffering on the peoples of many countries, especially the countries of Asia. I humbly accept this historical truth, and once again expressing my acute reflection and my sentiment of heartfelt apology, I offer my condolences to all the domestic and foreign victims of the previous great war. Without allowing the lessons of a cruel war to fade, I am determined to contribute to global peace and security without once more exchanging the fires of war. ${ }^{7}$

\footnotetext{
${ }^{4}$ Ibid.

5 Asahi Shinbun, 4th March 2015.

${ }^{6}$ See also interview with the 91 year old Murayama in Asahi Shinbun, 16th March 2015.

${ }^{7}$ Asahi Shinbun, 4th March 2015.
} 
The one thing missing in this paragraph was in the Murayama statement's paragraph from which it was derived is any reference to "mistakes" or "mistaken policies".

Despite the close similarities between the Murayama and Koizumi statements, the latter takes on a rather ritualistic quality when we consider that Koizumi on several occasions as Prime Minister, and despite knowing how provocative this was to China and South Korea in particular, visited the Yasukuni Shrine to the war dead in Tokyo.

\section{Other Apologies}

Very early in the occupation, the Shōwa Emperor (on the throne 1926 to 1989), told General MacArthur that he personally accepted responsibility for the war, though MacArthur as Supreme Commander Allied Powers does not seem to have accepted it. In September 1984 he apologized to the South Korean President in the following terms that some would regard as falling short of an apology:

It is indeed regrettable that there was an unfortunate past between us for a period in this century, and I believe that it should not be repeated again. ${ }^{8}$

His son, the present Emperor as of 2015, made apologies to successive Korean Presidents in May 1990 and October 1996. In apologizing for suffering brought upon Korea by Japan, he added, in the 1990 apology: "I cannot but feel the deepest remorse", and in the 1996 apology: "The deep sorrow that I feel over this will never be forgotten",

It should be remembered here that under the 1947 Constitution the Emperor only acts officially on the advice of his ministers, but an apology by an emperor is of great symbolic importance. Moreover, acts of omission can also have deep significance. Since the "enshrinement" of the souls of 14 Class-A war criminals (so designated by the Tokyo trials after the war) at the Yasukuni Shrine in Tokyo in 1978, neither the Shōwa Emperor nor his son the Emperor Akihito, have visited the Shrine, though plainly successive governments have urged them to do so (It should be noted that there are no mortal remains at the Shrine). Prime ministerial visits to the Shrine remain a serious bone of contention with China and Korea, and led to sharp deterioration in relations both under Koizumi and Abe.

In addition, prime ministers, foreign ministers and other senior ministers of the Japanese cabinet have proffered war apologies, either of a general nature or specific to other countries (especially China and South Korea), ${ }^{10}$ with some regularity over the years. Something of a "war apology industry" has developed, where the precise wording used on each occasion was subject to careful scrutiny by the media. The phenomenon of "war apology fatigue" also became apparent among government ministers, as the recipients of various war apologies reacted critically to them. Part of the problem was, however, that the effect of some apologies was undermined by subsequent "off-message" comments by senior figures in government, and others.

Shortly before he came to office, the first prime minister in a non-LDP government for three decades, Hosokawa Morihiro, made a war apology that was notably less formulaic and more trenchant than most of the ones that had gone before. It contained the following sentence:

\footnotetext{
${ }^{8}$ Quoted in "List of war apology statements issued by Japan", Wikipedia.

9 Ibid.

10 Between 1957 and 2012, war apologies were made by prime ministers Kishi Nobusuke, Tanaka Kakuei, Suzuki Zenkō, Nakasone Yasuhiro, Takeshita Noboru, Kaifu Toshiki, Miyazawa Kiichi, Hosokawa Morihiro, Obuchi Keizō, Koizumi Junichirō, Fukuda Yasuo (in a joint communiqué with China, omitting o-wabi and hansei), and Kan Naoto. Ibid.
} 
I myself believe it was a war of aggression, a war that was mistaken. ${ }^{11}$

A few weeks after Hosokawa delivered this message, the author was standing on the roadside somewhere in central Tokyo listening to a man speaking through a loud speaker on a truck belonging to an ultra-rightist organization, denouncing in uncompromising terms the Hosokawa war apology. So far as the author could see, he was the only person actually listening to this man, but the prevalence of this kind of activity was well known in China and elsewhere in Asia.

\section{The "Comfort Women" Issue}

From the 1990s the issue of women from various Asian countries who were placed in army brothels to service the soldiery became a matter of acute controversy between the Japanese Government and the Government of South Korea in particular. These women were given the euphemistic title of ianfu (generally translated as "comfort women") The issue became embroiled in the question of compensation, and the linkage between compensation and apology. The "comfort women" issue continues to resonate today, and has been the subject of a recent acrimonious dispute between the Abe Government and the Asahi Shimbun, which the Government accused of publishing a false report on the alleged coercive imprisonment of these women in army brothels. $^{12}$

On 4th August 1993, in the dying days of the single party (LDP) Miyazawa Government, the Chief Cabinet Secretary, Kōno Yōhei, who was shortly to succeed Miyazawa as LDP President (but not as prime minister since the LDP fell from power on 9th August) issued on behalf of the Government an apology to the surviving "comfort women" in the following terms:

Undeniably, this was an act, with the involvement of the authorities of the day, that severely injured the honor and dignity of many women. The Government of Japan would like to take this opportunity once again to extend sincere apologies and remorse to all those, irrespective of place or origin, who suffered immeasurable pain and incurable physical and psychological wounds as comfort women ${ }^{13}$ (author's italics).

Kōno made this statement at a time of intense negotiations with the South Korean side involving interviews with surviving former "comfort women", so that the Kōno statement was the fruit of understandings between the two sides. It did not, however, bring to an end the controversies surrounding this issue. Whether the women concerned had been genuinely coerced into prostitution, how badly they had been treated at the "comfort stations", the fact that prostitution was not illegal in pre-war and wartime Japan, the lack of surviving written materials demonstrating coercion, and above all, whether it was the Japanese army and civilian authorities during the war that had been directly responsible for recruiting them, were controversies that continued to rumble on over the next two decades, as does the vexed issue of compensation.

The issue of war apologies took a new turn with the emergence of Abe Shinzō as prime minister, both in his 2006-2007 administration and in his current administration that began in December 2012 (renewed by his election victory in December 2014). The author wishes to argue that Abe has developed a particular strategy for handling war apology issues, combining apparent agreement with official apologies made in the past, while at the same time by various means throwing doubt on their veracity. The Asahi Shimbun inadvertently played in

\footnotetext{
11 Recalled in Asahi Shinbun, 4th March 2015.

12 Asahi Shinbun, 5th August 2014; Japan Times, 5th August 2014.

13 Ministry of Foreign Affairs, Tokyo, Statement by the Chief Cabinet Secretary Yohei Kono on the result of the study on the issue of "comfort women", 4th August 1993.
} 
the hands of the Abe Government, when it gave publicity to allegations of coercion in the recruitment of "comfort women" by an individual called Yoshida Seiji, who later confessed that his statements were false. ${ }^{14}$

Before the author tackles the issue of Abe's strategy, however, he wishes to introduce two different kinds of scepticism about war apology.

The first is that of Hashimoto Tōru, the right wing radical Mayor of Ōsaka and head of the opposition party known as Ōsaka Ishin no kai (Osaka Restoration Association), which been winning around 40 seats in recent general elections for the House of Representatives (though it has now split).

Hashimoto has said in a number of public statements that comfort women were "necessary" for the Japanese armed forces, and that in time of war women are "necessary" for armies in general. In his words:

I myself think they are necessary, but it is mistaken to believe that I endorse this. The comfort women system is a system that all armies had. I won't say that it was a good thing, but it was the situation at the time. When soldiers are risking their lives in a rainstorm of bullets, then if you think that they should be able to rest somewhere, anybody will understand that the "comfort women" system was necessary. Japan is seen as a "country of rape" in Western countries, but that is wrong. ${ }^{15}$

The second kind of scepticism was expressed by the President of the International University (Kokusai Daigaku), professor Kitaoka Shinichi, a well known academic who has acted as an adviser to Prime Minister Abe and also led a team of Japanese historians discussing with their Chinese counterparts how the past history of relations between the two countries should be understood and presented. In a discussion group held on 10th April 2015, Kitaoka was quoted as expressing the following views:

The media is only interested in whether the key words of the Murayama statement are incorporated [into later statements]. "Invasion", "colonies", "acute remorse", "apology". But it is natural that what is said 50 years after the war and what is said 70 years after the war should differ to some extent. Are we arguing that the same words should be used 100 or 200 years after the event? Such a stupid thing is impossible. I think it makes sense for the Prime Minister to say that it is fine to follow [the earlier war apologies] in general terms (zentai toshite)".

Kitaoka went on to say that it was difficult to argue that the Manchurian Incident of 1931 was anything but an aggression (shinryaku), and that Japan went on to set up Manchukuo, which was a Japanese puppet state (kairai kokka), which no historian would dispute. He declared that he would like Abe to say that Japan committed aggression, but to admit aggression on this day, and to write the same thing in a [formal] statement, were two different things. On the question of "apology", he thought that it was better to use the word hansei (remorse), rather than shazai (the more formal word for apology), and concluded: "Given that so much time has elapsed, to talk of shazai sounds empty to me". ${ }^{16}$

To the outsider, Kitaoka's analysis (assuming it was correctly reported) sounds confused, and appears to imply that it is acceptable to repeat earlier war apologies so long as their essential content is removed. It is surprisingly difficult to see that this could carry serious intellectual conviction. This, however, may not be the point.

In the opinion of this author, Prime Minister Abe together with his Chief Cabinet Secretary, Suga Yoshihide, have put a much more effective political gloss on the issue than either the barely qualified endorsement of the "comfort women" system by Hashimoto, or Kitaoka's confused attempt to justify Abe's approach to the matter. Abe during his first administration devised a cabinet resolution that:

\footnotetext{
${ }^{14}$ Asahi Shinbun, 23rd November 2014.

15 Asahi Shinbun, 28th January 2013.

16 Asahi Shinbun, 11th April 2015.
} 
In materials unearthed by the government, no evidence has been discovered showing that coercion (kyōsei renkō) was directly applied in the recruitment and treatment of comfort women.

In a discussion in the right wing journal Seiron in February 2009, he said: "Japan is not bound for ever by the personal historical understanding of Mr. Murayama. The Murayama statement was too one-sided, and I should like to come up with something more balanced".

In an interview with the journal WILL in the same month, he said: "It is a big mistake to teach the Murayama statement as historical understanding". 17

Later, at the time of the LDP presidential election, Abe said that Japan did not have to bear the ignominy of soldiers having entered people's houses, kidnapping girls and making them prostitutes. ${ }^{18}$

Following his return to office, however, in December 2012, Abe with his Chief Cabinet Secretary adopted the stance that they had serious doubts about much of the evidence on which the Konno statement of 1993 was based, they gave strong hints that they wanted to reopen the issue, and even spoke about "collusion" with the Korean side in the researches conducted at the time (including interviews with former "comfort women"), that underpinned the apology made by Kōno Yōhei. But when the South Korean Government strongly objected to this, Abe backed down to the extent of declaring that the Government continued to accept the text of the Kōno statement (Whether the two things were causally connected is unknown to the author). More recently, in a television interview on 20th April 2015, he suggested that there was no real point in simply reading out Murayama and Koizumi war apologies, all that was needed was to say he accepted them, and leave it at that. ${ }^{19}$

My interpretation of the motives behind this apparently contradictory approach is as follows: On the one hand, Abe and Suga were endorsing war apologies that had stood the test of time and whose amendment would have caused great difficulty with South Korea. But on the other hand, by speaking publicly a great deal about what they saw as the flaws in the investigations that had led to the Konno statement, they had substantially undermined its credibility to a Japanese audience, and thus boosted their nationalistic credentials at home. The Japanese word that comes to mind is honenuki ni suru (to take the bones out of it, while leaving the outward shape). It seems, however, that the government in the republic of Korea understood perfectly well what was going on, and remains deeply suspicious of the motives and ideological drive of the Abe Government and the nationalist forces that it represents.

\section{The Abe Statement of 15th August 2015}

Finally, let us consider the long statement delivered by Mr. Abe on the 70th anniversary of the end of the war, 15th August 2015.

The statement gives ample evidence of having been carefully considered and honed with the aim of satisfying several different constituencies. On the one hand, and most obviously, the Prime Minister needed to assure neighboring countries that the language of past prime ministerial, and other, apologies had not been jettisoned, and so the established language of "apology", "remorse" and so on was retained.

Almost half-way into the speech, Abe even goes so far as to quote the language of his bête noir, the "Peace clause" of the 1947 Constitution, that: "we shall never again resort to any form of the threat or use of force as a means of settling international disputes". Some lines later, he continued:

\footnotetext{
17 Both these statements as quoted in Asahi Shinbun, 30th January 2015.

18 Ibid.

19 Asahi Shinbun, 21st April 2015.
} 
Japan has repeatedly expressed the feelings of deep remorse and heartfelt apology for its actions during the war. In order to manifest such feelings through concrete actions, we have engraved in our hearts the histories of suffering of the people in Asia as our neighbors: those in Southeast Asian countries such as Indonesia and the Philippines, and Taiwan, the Republic of Korea and China, among others; and we have consistently devoted ourselves to the peace and prosperity of the region since the end of the war. Such position articulated by the previous cabinets will remain unshakable into the future. ${ }^{20}$

There is more in the speech to similar effect. But it is balanced also by an attempt to explain the history in ways that, while not exonerating Japan from blame, elucidate what Japan did in terms of difficult international circumstances facing its decision makers. Thus, at the beginning of the speech, after referring to the effects of nineteenth century Western imperialism in stirring Japan to achieve modernization, and identifying the horrors of the First World War as the crucible for efforts to establish durable peace (including the establishment of the League of Nations), the Prime Minister went on:

At the beginning, Japan, too, kept in step with other nations. However, with the Great Depression setting in and the Western countries launching economic blocs by involving colonial economies, Japan's economy suffered a major blow. In such circumstances, Japan's sense of isolation deepened and it attempted to overcome its diplomatic and economic deadlock through the use of force. Its domestic political system could not serve as a brake to stop such efforts. In this way, Japan lost sight of the overall trends in the world.

... Japan gradually transformed itself into a challenger to the new international order that the international community sought to establish after tremendous sacrifices. Japan took the wrong course and advanced along the road to war. ${ }^{21}$

Much of the speech concentrates on Japan's recovery and rehabilitation after the war, and acknowledges "goodwill and assistance extended to us that transcended hatred by a truly large number of countries, such as the United States, Australia, and European nations, which Japan had fiercely fought as enemies". ${ }^{22}$ Japan's own sufferings in the war, including three million dead, wholesale destruction from the air, including the atomic bombing of Hiroshima and Nagasaki and the terrible battle for Okinawa, are outlined more than once, but not at great length.

There is a rather remarkable passage concerning China:

How much emotional struggle must have existed and what great efforts must have been necessary for the Chinese people who underwent all the sufferings of the war and for the former POWs who experienced unbearable sufferings caused by the Japanese military in order for them to be so tolerant nevertheless ${ }^{23}$

Curiously enough, apart from an early mention of the Russo-Japanese War (1904-1905) having given "encouragement to many people under colonial rule from Asia and Africa", the speech contains no reference to Russia or the Soviet Union.

The contentious "comfort women" issue is mentioned twice, very briefly, including the following passage:

We must never forget that there were women behind the battlefields whose honor and dignity were severely injured.

There is no mention in this of the consequent difficult-to-eradicate sexually transmitted diseases and other medical problems so many of them suffered (though, as we have seen, it was referred to in the 1973 Kōno statement), nor of the fact that hardly any of them were ethnic Japanese, nor the fact that any mention of

\footnotetext{
${ }^{20}$ Asahi Shinbun, 15 August 2015. Most unusually, the (Japanese language) Asahi Shinbun gives the text of the speech both in Japanese and English. These quotations are from the English version.

21 Ibid.

22 Ibid.

23 Ibid.
} 
"comfort women" had been removed from school textbooks, nor indeed that the Abe Government and its supporters have been strenuously denying that recruitment of women for army "comfort stations" had been the responsibility of the Imperial Armed Forces. Indeed, rightist campaigning on this issue has been going on with increasing intensity since the 1990s.

On the face of it, Prime Minister Abe's 70th anniversary speech appears to be a fulsome recognition of, and apology for, the iniquity of much Japanese behavior during the Asia-Pacific War from 1937 to 1945, but it contains one revealing passage that brings to the fore the issue of "apology fatigue". As we have seen, there have been many apologies, of varying degrees of detail and strength, since the war, and it is not entirely surprising that Japanese leaders should grow tired of repeated demands for more and more apology, when they feel they and their predecessors have apologized enough for events now over 70 years in the past. This sentiment is shown vividly in the following passage from Prime Minister Abe's speech:

In Japan, the post-war generations now exceed $80 \%$ of its population. We must not let our children, grandchildren, and even further generations to come, who have nothing to do with that war, be predestined to apologise. Still, even so, we Japanese, across generations, must squarely face the history of the past. We have the responsibility to inherit the past, in all humility, and pass it on to the future. ${ }^{24}$

We may indeed discover some force in this argument, and in addition, China on occasion has demanded apologies from Japan, as well as encouraging anti-Japanese demonstrations, to divert attention from its own economic problems. It also allows dissidents to let off steam by directing their ire against Japan. China of course, as a nascent super-power with expansionist ambitions, prefers a pacifist Japan to a Japan in effective military alliance with the United States. In South Korea, for historical reasons, anti-Japanese feeling is easy to mobilize, especially as Japan maintains a claim to some uninhabited rocks in Korean possession in the East China Sea, known as Dokdo in Korean, and Takeshima in Japanese. The "comfort women" issue also continues to poison relations between the Republic of Korea and Japan.

But the fact that Japan has so often faced demands for yet more apologies may not be so surprising when we contrast Japanese official attitudes towards an uncomfortable past with official attitudes and actions over the years in Germany. When the West German Chancellor Willy Brandt spontaneously joined a Holocaust memorial demonstration in Warsaw in December 1970, he fell on his knees in his famous Kniefall, uttering not a word, and later wrote of this: "Carrying the burden of the millions who were murdered, I did what people do when words fail them" (Nakano, 2015a). Germany also paid huge sums to Israel and to Jewish survivors of the Holocaust after the war, whereas Japan has always rejected demands for compensation, including, most contentiously, to former "comfort women" in Korea and elsewhere. For Japan, there is of course no counterpart of the Holocaust, but the casualties inflected on Chinese and other populations are in the millions.

In February 2015, Prime Minister Abe had set up a commission to advise him on what he should say in his projected 70th anniversary statement, and perhaps the most influential member was the Deputy Chairman of the commission, the above-mentioned Professor Kitaoka Shinichi, a serious scholar and close confidant of the Prime Minister. It is uncertain just how far the commission influenced his speech, since he was known to set up commissions and then ignore their findings. In any case, as pointed out by the Australian scholar, Morris-Suzuki, T. on the commission non-historians greatly outnumbered historians, and in any case the report did not much cover historical issues (Tessa, 2015). Whether so influenced or not, the historical accounts given

24 Ibid. 
in the Abe statement are distorted. For instance, it shows no accurate understanding of why Japan took Taiwan as a colony in 1895 and Korea in 2010, nor does it mention the presence of Japanese troops in China long before the Manchurian Incident of 1931, and such episodes as the "Twenty-one Demands" given to China in January 1915, as well as confusing the causality behind the Manchurian Incident and the Pearl Harbour attack a decade later (Tessa, 2015).

In an article in the Japan Times, the former British Ambassador to Japan, Sir Hugh Cortazzi, welcomes some positive items in the speech, but points out a number of absolutely crucial omissions in the historical account. Most importantly, no mention was made of the Nanjing massacre of 1937 (with numbers of those murdered by Japanese troops disputed, especially by supporters of Mr Abe, but the fact of a huge massacre not in doubt), Japan's adherence to the Axis Pact of September 1940 with Nazi Germany and Fascist Italy, the manipulation of State Shinto for political ends, the extremist cult of the Emperor, leading to increasingly repressive military dominance, or the Japanese take-over in the 1930s of Manchuria, which became a Japanese-controlled puppet State (Cortazzi, 2015).

\section{Conclusions}

This survey of Japanese high-level war apologies over recent decades suggests the following conclusions.

On the one hand, the war apology issue has become one aspect of a developing geo-political situation in East and South-East Asia, Countries neighboring Japan rightly perceive that the ways in which Japan has attempted to handle the issue of war responsibility constitute a serious area of Japanese political vulnerability, which they (particularly China) do not hesitate to exploit. Japanese attempts to deal with this find leaders falling between the two stools of glorifying Japanese identity and sticking with previous apologies so as to avoid increased external pressure.

On the other hand, the political outlook of Japanese governments has moved much further to the right since the late 1ate 1990s, and this trend has accelerated since the election of the second Abe Government in December 2012 (Nakano, 2015b; Nakano, 2015c). Admittedly, the DPJ-led Government from 2009 to 2012 made some attempt to reverse this trend, but the ultimate failure and consequent electoral rout of that government gave an unusual opportunity for the LDP, now under the energized right wing leadership of Abe Shinzō, to press its electoral advantage and pursue nationalistic and right wing agenda with few of the political obstacles facing its predecessors. It is less certain, however, that public opinion has moved so far to the right as has government policy. An analysis of public opinion is beyond the scope of this article, but although substantial sections of the electorate support current policies of economic regeneration, many public opinion polls reveal that support for the 1947 "Peace Constitution", whose peace clause the government wishes to revise, remains strong, and is probably a majoritary, which may mean that revision can be blocked.

The apology issue therefore needs to be analyzed in the broader context of a set of policy ambitions on the part of the Abe Government, encompassing constitutional revision, military expansion (within the American alliance), a more authoritarian approach to human rights, greater control of the mass media, reduced rights of scrutiny over government activities, and concerted campaigns of historical revisionism. Despite some pro-democracy language in Prime Minister Abe's 70th anniversary statement, these policies taken as a whole represent a serious watering down of the well established democratic norms that have largely prevailed in Japanese politics since the late 1940s. The American historian Gluck, C. in a lecture in Oxford on 30th October 2015, argued that recent developments in Japan reflected a widespread international trend towards government 
from the far right, and compared the Abe regime in Japan with that of President Erdogan in Turkey and President Modi in India (Gluck, 2015). It would be wrong, of course, to take this comparison too far. The circumstances of Japan, India and Turkey are in many ways different. Freedom of expression in Japan is no doubt more extensive than in either of those two countries. ${ }^{25}$ Comparisons could also be made with China and Russia that would place Japan in a favorable light by comparison. Nevertheless, the intentions of the Abe Government are clearly to restrict human rights and freedoms by revising Chapter 3 of the 1947 Constitution (on rights and duties of the people) away from citizens' rights and toward duties to the State, which also, to cite one example out of many, maintains tight control over school textbooks, excising references to such embarrassing issues as "comfort women" that might lead schoolchildren to doubt the noble mission of Japan during the Pacific War. We might also refer to the Designated Secrets Law of December 2013, which provides severe punishments for journalists seeking to discover the truth about government behavior. The problem, in other words, is one of the trajectory upon which Japan is embarked under the Abe Government.

Why then, given these Japanese political developments, should Prime Minister Abe have retained practically all of the "gold standard" terms from previous apologies (most notably, those in the Murayama statement of August 1975), in a discourse seeking to reiterate the "national identity" theme, forcefully expressed in his earlier writings (Abe, 2016)? The present author believes that the answer to this question is quite simply that to be seen to retreat from these positions, and this specific language, would have risked obstructing his plans for even limited reconciliation with China and South Korea that he currently sees as necessary for Japan's national interest and long term security.

If we look back to the 1990s, we see that the Japanese political spectrum was then much more extensive and balanced than it has since become. In particular the ruling Liberal Democratic Party has become monolithic, whereas it was previously much more of a "broad church" of rival factions. The far right was always present within the LDP, but was balanced by powerful elements that could be described as "moderate conservative". As of 2015, it is hard to find such groupings within the ruling party. And moreover, the opposition parties are currently much weaker than they were in the 1990s.

It is difficult, therefore, to escape the conclusion that, had it been moderate conservatives rather than right wing radicals now holding the reins of power in Japan, not only the war apology issue, but also relations with neighboring countries in general, would have been much easier to handle than they are at present. And moreover, in so far as an expansionist China can be seen as a regional threat, the fact that the Japanese Government is issuing apologies with one hand and self-justification with the other, provides an effective stick with which China can belabor Japan whenever it is convenient to do so.

Even though "apology fatigue" is to some extent understandable among Japanese political leaders, given the hard line against Japan, even in the face of genuine apology, that some neighboring states have maintained, there seems little doubt that the war apology manoeuvrings engaged in by Abe and his Government have contributed significantly to a worsening of Japanese relations with China and the Republic of Korea (and to some extent also with the United States), and have stirred up unpleasant historical memories that most of us had assumed had entered the realm of real history rather than remaining as a part of contemporary international politics. On 28th December 2015 the foreign ministers of Japan and South Korea signed an agreement that, among other things, provided for a compensation fund for surviving 'comfort women'. This was a welcome

25 Retrieved from https://freedomhouse.org/sites/default/files/FOTP\%202013\%20fULL\%20Report.pdf; and http://en.rsf.org/world-press-index-2015-12-o2-2015-47573.html 
development, though how far it would improve Japan-ROK relations in the long term remained to be seen.

\section{References}

Abe, S. (2006). Utsukushii kuni e (Towards a Beautiful Country). Tokyo: Bunshun Shinsho. (Republished, with revisions, 2013). Cortazzi, H. (2015, August 17). History should be based on fact not myth. Japan Times.

Gluck, C. (2015). Future past entanglements: Modern Japan and the work of history. Lecture at the Nissan Institute of Japanese Studies, University of Oxford,.

Ministry of Foreign Affairs. (1993). Statement by the Chief Cabinet Secretary Yohei Kono on the result of the study on the issue of "comfort women", 4th August 1993, Tokyo.

Morris-Suzuki, T. (2015). Abe’s WWII Statement Fails History 101. From East Asia Forum (Canberra), 26th August 2015.

Nakano, K. (2015a). Japan's security "normalization" and historical revisionism in the Contemporary East Asian context. Lecture for the Ecole des Hautes Etudes en Sciences Sociales (EHESS), Paris.

Nakano, K. (2015b). New right transformation in Japan. In K. Nakano and M. R. Mullins (Eds.), Disasters and social crisis in contemporary Japan: Political, religious and sociocultural responses (pp. 23-41). Basingstoke and New York: Palgrave Macmillan.

Nakano, K. (2015c). Ukeika suru Nihon seiji (Japanese politics moving to the right). Tokyo: Iwanami Shinsho.

Yakushiji, K. (Ed.). (2012). Murayama Tomiichi kaikoroku (Memoirs of Murayama Tomiichi). Tokyo: Iwanami Shinsho, 2012. 